\title{
The Malari 1974, Press and the Soeharto's New Order: A Historical Reflection on Student Movement in the Authoritarian Era
}

\author{
Herdi Sahrasad $^{1}$, Muhammad Ridwan ${ }^{2}$ \\ ${ }^{1}$ Associate Professor, Universitas Paramadina, Jakarta \\ ${ }^{2}$ Universitas Islam Negeri Sumatera Utara, Indonesia \\ sahrasad@yahoo.com
}

\begin{abstract}
This article argues The Malari 1974 incident was triggered by a series of protests carried out by the opposition and students against foreign capital, which in this case were owned and Japanese outbreaks of fraud and corruption committed by officials in the New Order period, Hariman Siregar, the leader of Malari 1974 student movement himself, argued that this event was an anticlimax of the alliance between the campus and the military under Soeharto which was so warm in the previous times, namely in 1966 which was campus, in this case represented by students together with the military same to bring down the Old Order regime that was in power at the time. But that did not last long, because the alliance was then broken when students as a moral force found their critical reasoning again in criticizing the New Order government, which at the time was said to have deviated from the message of the actual suffering of the people. This then led to the Malari incident as an appropriate means to get rid of "opponents" who tried to overthrow the New Order power. At that time there were around 12 banned print media, such as: Nusantara, Indonesia Raya, Pedoman, KAMI, Mahasiswa Indonesias, The Jakarta Times, Abadi, Suluh Berita, Pemuda Indonesia, Pos Indonesia, Wenang weekly and Ekspress magazine. The government accused the press of being partially responsible for the Malari incident. The press is considered to have participated in finalizing the political situation which later exploded into riotous actions which claimed lives and material.
\end{abstract}

Keywords

demonstration; student movement; malari; Hariman Siregar, orde baru, Soeharto, press media

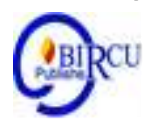

\section{Introduction}

The student movement in Indonesia post colonial, as is generally the case in the Third World, plays an important role as the control of the educated for various abuses by the ruling regimes in the developing countries. Press /Media reports and analysis show that the 1974 student demonstrations in Indonesia have historical threads with previous student movements.

In this context, Julian Benda in his work The Betrayal of Intellectuals (La Trahison des Clercs,) describes intellectuals as ideal human beings who have the principle of "my kingdom not on this earth". This means that intellectuals are constructed as human beings who have no worldly interests. Intellectuals involved in the world of politics, for Julian Benda is seen as a manifestation of "the Betrayal of the Intellectual ". Benda is more or less willing to say that the ancient ideal intellectuals were moralists whose activities 
constituted resistance to mass realism. Julian Benda's work on "the Betrayal of the Intellectual" was the foundation of the moral movement in Indonesia.

The pioneers of the power of morality include Soe Hoe Gie and Soe Hok-Djin (Arief Budiman), two brothers who study at the University of Indonesia and also students of generation 1966 who often quote Julian's work as the foundation of their morality ideas.

Soe Hok Gie and Arief Budiman, two student activists, gave their ideas and thoughts to the articulation of their moral movements in a series of writings in newspapers since the beginning of 1967 (Maxwell, in Aspinall, 2012: 166). Soe Hoe Gie and Soe Hok-Djin were part of the student activist leadership of generation 1966 and loudly demanded that Soekarno step down and support the destruction of the left and the rise of pro-Soeharto civil and military forces.

The most important event towards the end of the 20th century was the eruption of the 1998 student movement which succeeded in forcing the resignation of President Soeharto who had been in power for 32 years. The 1998 student movement was the culmination of the 1974 student movement (Peristiwa Malari 1974); the 1977/78 student movement and the 1980s not extinguished its enthusiasm to correct the authoritarian New Order.

Masminar Mangiang noted, variations in student movements such as the Anti-Corruption Committee, the white group in the 1971 General Election, and the rejection of the construction of the Beautiful Indonesia Miniature Park (TMII) and the Marriage Bill during the 1970 to Malari Events 1974 were indications of increasingly heated relations between Soeharto government and students.

\section{Review of Literatures}

\subsection{Atmosphere Approaches the 1974 Student Movement}

In the last months of 1973 to the beginning of 1974, the temperature of the battle in the body of power in the layers just under Suharto continued to increase. One of the strong groups in the competition for power struggles was General Soemitro's group, who at that time was in a powerful position as the Kopkamtib Commander. Other groups are Aspri group Maj. Gen. Ali Moertopo and Maj. Gen. Sudjono Hoemardani, who are known to have a complete line of semi-formal intelligence. Outside of this group, there was a technocrat group Widjojo Nitisastro and friends who began to feel uncomfortable in their inner relations and interests with Soeharto.

In the student critical movement 1970-1974 Hariman Siregar represented the Jakarta group in the mainstream of the strength and movement of Indonesian students. Whereas the other main groups are the Bandung student group, mainly by three prominent campuses, ITB-Padjadjaran Universit Parahyangan University. Unlike the Bandung students, it seems that Jakarta students in the 1970s faced a variety of more complex problems. One thing is obvious, the influence of extra universiter organizations in the intra-campus student government body is still very strong, continuing the atmosphere of campus politicization from 1960-1965. This makes the situation of movement on behalf of the campus more complicated.

Every extra organization through an extension of their respective hands moves individually to utilize movements on behalf of the campus for the benefit of their respective parents - both the parent organization and the parent of political groups or groups within the body of power. On the Jakarta campuses, it can be seen, for example, how HMI (Himpunan Mahasiswa Islam- Islamic Student Association) has its own purpose and agenda of interest or political agenda, so much the experiment has colored the student 
movement for its specific interests. While in some other specific campuses, the dominance of other extra organizations also does not miss doing the same thing.

Leo Tomasoa confirmed this latest accusation without mentioning which party he intended. Hariman they mentioned a thousand-faced, small dictator who had sold the University of Indonesia. However, not a single charge from the motion group dared to mention the relationship between Hariman and General Soemitro's group. Hariman himself denied his relationship with any party except Golkar through the coordination of Pemacen (the Youth-Students-Scholars, Pemuda, Mahasiswa, and Cendekiawan-Permacen), which he admitted helped him become Chairman of the DM-UI.

It is interesting that, along with the radicalization of Jakarta students in the last months of 1973 to the beginning of 1974, the temperature of the struggle in the body of power in the layers just under Suharto also increased. One of the strong groups in the competition for power struggles was General Soemitro's group, who at that time was in a powerful position as the Kopkamtib Commander. Other groups are Aspri group Maj. Gen. Ali Moertopo and Maj. Gen. Sudjono Hoemardani, who are known to have a complete line of semi-formal intelligence. Outside of this group, there was a technocrat group Widjojo Nitisastro and friends who began to feel uncomfortable in their inner relations and interests with Suharto. These three groups, as of that moment, cannot be considered as strategic friends whose loyalty to Soeharto can be guaranteed. Around the groups there were also a number of generals and figures who were not "clear" but were always careful in calculating the direction of the wind.

"In what ways do students carry out the demands of the nation's conscience? With the power struggle movements on the street that come into contact with practical politics or with movements that rely on the power of thought and concept as moral strength according to the nature of their role as young intellectuals? Or is it a smart and wise mix of all ways? " DM-UI activists said.

Between Bandung-Jakarta. In the last months of 1973, after the August 51973 event in Bandung, campus-based student activities increased. Many inter-campus meetings are held. Whether it is between Bandung campuses themselves, as well as with other city campuses such as Surabaya, Yogya, Bogor and Jakarta. In addition to students, there are often other critical movement exponents in the community, both cultural and intellectual.

One of the meetings that received the attention of the authorities was a meeting on the ITB campus which was reported by the press as 'Dissatisfied People's Meeting'. Other student meetings observed by the power circles were meetings before the January 15, 1974 event, on the campus of the University of Padjadjaran, which was attended by leaders of student councils who were not expected by the authorities to 'consolidate' namely ITB, UI and Unpad. In the meeting attended Hariman Siregar from DM-UI, Komarudin from Dewan Mahasiswa ITB (DM-ITB) and Hatta Albanik from DM-Unpad as the host. Also present were several other DM leaders from Bandung and outside Bandung. But what was most observed by the intelligentsia at that time was the three people.

Towards Malari 1974, the arrival of the Chairperson of the Inter Governmental Group on Indonesia (IGGI), Jan P Pronk in Jakarta on Sunday, November 11, 1973, was welcomed by students with anti-foreign capital demonstrations at Kemayoran Airport, Jakarta. The event then culminated with the eruption of the anti-foreign capital student movement, expanding and culminating on the arrival of Japanese Prime Minister Tanaka, January 15, 1974. 


\subsection{Procession of Eruption Malari 1974}

On January 12, the head of the DMUI, Hariman Siregar stated that a movement to welcome Tanaka would be held to inform that the Indonesian people still had national pride and there were still many people who could not be bought with property. This statement was then the opening phase of the student demonstration movement in greeting Prime Minister (PM) Tanaka on January 14. This was then realized with a massive demonstration on that date determined, in protest against the arrival of Japanese Prime Minister at Halim Perdanakusuma airport, although it failed to break in because security officers swiftly blocked the demonstrators with unsheathed weapons. The students, in this case also no longer pay attention to warnings from Laksana Sudomo and Minister of Defense M. Panggabean who began to offend the student movement "as something that is not pure and leads to treason." Student actions that had been a moral force to do control and criticism, continue to nag and move, especially after the "contact" between student demonstrators and the Japanese PM Tanaka cannot occur due to layered escort from the security forces.

As a result, this increased the political temperature that had happened at that time. In the evening, held at the University of Indonesia Student Center, dozens of representatives of the Student Council (Dema) from Javanese universities, led by the UI Student Council held a meeting to evaluate the demonstration to welcome the arrival of Japanese Prime Minister Kakuei Tanaka. This preparatory meeting was led by Gurmilang Kartasasmita, the deputy chairman of the DMUI as well best friend from Hariman Siregar. Two themes discussed were plans for dialogue with Tanaka and the route of the demonstration. After agreeing, the meeting was finally closed half an hour after the turn of the day. Some of the masses slept in the UI campus as the basis of the movement, while the rest chose to return home to then take part in the demonstration together in the morning.

The following morning, dated January 15, 1974, demonstrators consisting of students and non-campus activists gathered at the University of Indonesia Student Council (DMUI) Secretariat, Jalan Salemba, Central Jakarta, to carry out the action. The mass action itself at that time agreed to the event and then focused on Trisakti University. By bringing the central theme with three demands, namely disbanding Aspri, lowering prices, and eradicating corruption which became known as "Tritura 1974", they began walking from Salemba around 08.00 to Jalan Raden Saleh, then to Cikini, Gambir, and Merdeka Timur. After the mass action then moved on to the National Monument. On the way, the number of demonstrators increased, mainly because of the high school students. Along the way the demonstrators lowered the flags to welcome state guests to half a pill as a sign of grief because of the arrival of Tanaka.

After the apples were dissolved, they returned to their homes. He did not say afterwards, "uncontrolled elements" outside the mass of students, where hundreds and thousands of mobs, among them containing thugs, rioters, and thieves then began making riots and acts that are not commendable: they burn Japanese cars, deflate tires, while ransacking shops, buildings and others. The DM- UI chairman, Hariman Siregar himself who knew about this after the student apple tried to control the masses who were so out of control at the time, but were unsuccessful. The following excerpts of the interview cited here:

("So, I myself told the community at that time to ask for a policy, I could sing first ..." "Go forward without fear" "No one can sing, now in my heart, this is a little chaotic, I think.... Seriously ... "our struggle is not for destruction", "we will return home first"). 
Through the Tempo forum, Abar tried to explore how the events we know more about the "Fifteen January 1974 plagues" incident took place. "In terms of the paralysis it caused to the life of the capital, people seemed to be able to compare it to the paralysis of Paris due to the riots there in May 1968. And the tensions felt by the residents of Jakarta last week, were like the tensions experienced by Peking residents broke out at Peking University at the height of the Cultural Revolution there. For the first time having goods made in Japan, especially motorized vehicles, for the Jakarta people last week was a burden of tormenting thoughts and a kind of sin. According to Sutarto (2019) Systematically from systematic discussions and studies and input from various parties, both from community leaders, academics and practitioners.

Mass riots continued until the next day even though various organizations had called for calm. Finally on the 16th night, DMUI chairman Hariman Siregar surrendered to the authorities, and then presented himself on a television screen to appease the demonstrators. He read a declaration from the University of Indonesia Student Council that opposed the violence.

\section{Research Method}

This paper will examine the dynamics of the 1974 student movement known as the Malari Event 1974 based on mass media/press reports and analysis. The mass media/press then it was suppressed by the New Order regime's rulers, just days after the 1974 Malari Event, because it was deemed by the government to be too siding with the aspirations and ideas of the students who conducted the demonstration. There were around 12 banned print media banned, such as: Nusantara, Indonesia Raya, Pedoman, Mahasiswa Indonesia, KAMI, The Jakarta Times, Abadi, Suluh Berita, Pemuda Indonesia, Pos Indonesia daily, Wenang weekly and Ekspress magazine.

In Indonesia, the 1974 student movement was the most dramatic and most popular student action at the beginning of the New Order, which was colored by riots that claimed lives and property. Later the 1974 Malari Event activists and actors became mentors for younger students as their next generation in the student movement, which reached its peak in May 1998 with the successful end of Soeharto's New Order regime.

As is known, at the Malari 1974 Event for two days the area around the capital city of Jakarta was covered in smoke. Burning and looting became a very worrying scene at that time. The Jakarta Senen shopping area became the focus of attention on January 15, 1974, dan The Minister of Defense and Security Maraden Panggabean was considering that the construction of shops that cost Rp. 2.7 billion was sold out by the red rooster. He said at the time that there were 11 people died, 300 were injured, quite a number of material losses incurred during the two days of recorded riots. Reportedly, a number of people were killed, at least 807 cars and 187 motorbikes damaged or burned, 144 buildings damaged or burned (including Coca-cola factories), and 160 kilograms of gold lost from a number of jewelry stores. 


\section{Discussion}

\subsection{Malari 1974: Symbol of Resistance}

Basically, all critical activities of students are driven by the same idealism. Therefore, student movements in one city are quickly appreciated by students from other cities in the form of similar movements. But the behavior and treatment of military rulers in each city is often not the same. The farther away from Jakarta, the more repressive.

Student movements are often expressed by the student movement in Jakarta as containing the nuances of practical politics, which in the past was often interpreted as a power struggle among the national political elite. The student movement in Bandung - and generally other student movements outside Jakarta - is more visible to contain a lower level of practical political content compared to the student movement in Jakarta which because of their position in the capital is easily labeled as a practical political movement.

Generally the student movement which is considered successful in overthrowing the power regime is when the student movement combines student movements with a practical power struggle in Jakarta with the forces of thought and idealism which are usually born in the student movement in Bandung. The ruler actually understands this so much that trying to undermine the chain that connects Bandung with Jakarta. Other university cities such as Yogyakarta, Surabaya, Medan, Makassar and Bogor by themselves also have certain characteristics which, if successfully connected to the Jakarta-Bandung axis, will also be a powerful force capable of breaking down any power of power that hinders student idealism.

The failure of the student movement on January 15, 1974 in Jakarta to replace Soeharto's power occurred because of the breakdown of the chain linking the movements of the students of Jakarta and Bandung, so that it automatically decided to also connect with the student movements of the main cities of other universities. One thing or another, it happened because of the emergence of a large 'suspicion' of the figure of Hariman Siregar whose political 'game' often confuses opponents and friends. The question arises to him: Who is he playing for? This impression seems to underlie the attitudes of Bandung student leaders, Hatta Albanik (Unpad) and friends in Bandung and outside Jakarta, including Tampubolon Muslim (ITB) who seemed not always 'harmonious' with Hatta.

It is undeniable, the various demands of Bandung students, very much colored the political decisions made by the government, such as the dissolution of Aspri, credit policies for entrepreneurs and small investments, and restrictions on luxury lifestyles such as among others the satirical contingents of Bandung students about the high like a prison in Jakarta but inside it is a palace, when a meeting took place 11 January 1974 with President Soeharto at Bina Graha.

Current BEM from various campuses in various movements tends to be merely a subordination of off-campus organizations such as Kammi (Kesatuan Aksi Mahasiswa Muslim Indonesia-Kammi) for example. Apart from the control of the initiative to move outside the campus fence, it naturally opens up opportunities for contamination of practical political interests in the student movement. In other words, there is an open opportunity for students to use in various intra-political political battles.

After the events of January 15, 1974, a number of suppression measures were implemented on campuses. Aside from the army, the suppression action was mainly through the hands of the Minister of Education and Culture who was appointed after Suharto's January 15 incident, namely Maj. Gen. Dr. Sjarif Thajeb. This suppression style became a mode for the authorities to face the campus until 1978. The peak was in the form 
of campus occupation which dared to 'fight' Soeharto such as ITB and several other universities throughout Indonesia, by army units in 1978.

Initially, Dr. Sjarif Thajeb, who had sat as Minister of Higher Education in the Soekarno transition cabinet in 1965-1966, had become a 'hope' for students, given his track record as someone who contributed to the birth of US (Indonesian Student Action Unit) which eventually became the spearhead of the overthrow of the Soekarno regime. However, his good words which were always conveyed in meetings with students, proved to be mere nonsense, because even he became one of the sword actions of suppression on campuses. Later he often made loud words that pressed students into various meetings. Therefore, many times he had an argument with the students. Even no one could guess the atmosphere of the father-son meeting that had happened at first, in the future it almost developed into a duel of fist fights when he wanted to impose his will.

But the campus has never really been subdued by power alone. Student critical movements in various ways can still take place, including by holding 'scientific' discussions under the umbrella of the Tri Dharma of Higher Education. Meanwhile, human resources for the campus never run out, each year the campus gets 'fresh blood' in the form of flowing in the entry of new students who in time bring new aspirations. College campus is like a river, the water never stops flowing. An endless process. History notes that after the student critical movements of 1970-1974, a student resistance movement emerged in 1978 and the subsequent 1998 student movement became the main ignition of Soeharto's fall.

Actually, so far the national conscience has always seen a red thread on student movements. It is clear that the more the ruler takes a distance from the student movement, then that means the age of power in the hands of the ruler, whoever he is, in any given time, has become shorter. However, it becomes an interesting question, in what ways do students carry out the demands of the nation's conscience? With the power struggle movements on the street that come into contact with practical politics or with movements that rely on the power of thought and concept as moral strength according to the nature of their role as young intellectuals? Or is it a smart and wise mix of all these methods?

\subsection{Soeharto's Footsteps and the Malari Event: "The Shadow of an Unseen Hand"}

In the book Autobiography of Soeharto (1989), the Malari 1974 case was passed over, not mentioned at all. Though about Petrus (mysterious shooting), Soeharto was quite for thright.

For the January 15, 1974 case, better known as the "Malari Event", it was recorded that at least 11 people died, 300 were injured, and 775 people were detained. A total of 807 cars and 187 motorbikes were damaged / burned, 144 buildings were severely damaged. As much as $160 \mathrm{~kg}$ of gold is lost from a number of jewelry stores. This violent event can only be experienced and felt (consequently). But not to be revealed thoroughly. News in the paper only reveals facts that can be seen with the naked eye.

The Malari incident occurred when Japanese Prime Minister Kakuei Tanaka was visiting Jakarta (January 14-17 1974). Students plan to welcome their arrival by demonstrating at Halim Perdanakusuma. Because they were tightly guarded, a group of students failed to break into the air base. On January 17, 1974 at 08:00, the Japanese PM departed from the Palace not by car, but was delivered by President Soeharto by helicopter from the Bina Graha Building to the air base. That shows that the atmosphere of the city of Jakarta is still tense. 
Tanaka is considered a symbol of foreign capital that must be eliminated. The action in the form of a long march from Salemba to Trisakti University in Grogol, West Jakarta, brought three demands: eradicating corruption, changing economic policies regarding foreign capital, and dissolving the President's Personal Assistant institution. Hundreds of thousands of people took to the streets. But this action then led to riots.

According to Hariman Siregar, the student action was over at 14.30. "While the riots occurred an hour later," he said. The masses who claimed to be from the workers stormed Pasar Senen, Blok M, and the Glodok area. They carried out looting and burned Japanesemade cars and shops.

The Commander of the Operations Command Restoring Security and Order General Soemitro was able to block the mob in the Sarinah area, Central Jakarta. He tried to deflect the mass movement that led to the Presidential Palace. "Come on, come with me, we will go together to Kebayoran!" "I mean, they want to make their goals deviate, so that they don't get to the National Monument ..."

The crowd did not move. To Tempo a few years ago, Soemitro claimed to have offered a dialogue between the UI and Tanaka Student Council. Tanaka was willing, but the DM-UI replied that "dialogue was replaced by street dialogue ..."

But Jakarta has already become an abang reef. That day dozens of people were killed, hundreds were injured, nearly a thousand cars and motorbikes were damaged and burned, and hundreds of buildings were damaged. This is still added by 160 kilograms of gold lost from a number of jewelry stores. So vulnerable, Soeharto had to take Tanaka to take a helicopter ride to Halim Airport before going back to his country.

Hariman Siregar, then Chair of the University of Indonesia Student Council, was dragged to court on charges of subversion. After four months of trial, he must bear the sentence of six years in prison.

"I am considered to undermine the authority of the state," Hariman said when we met in March 2006. The price he had to pay was too expensive. When inhabiting the prodeo hotel, his father died, his beloved wife was sick, and his twin children died.

The event known as Malari changed Indonesia's journey. Because, according to historian Asvi Warman Adam in an article, after that Soeharto systematically repressed. Sjahrir, who was arrested after the incident, considered Malari a form of consolidation of Suharto's power.In total the apparatus scratched 750 people, including student leaders and scholars, such as Hariman Siregar, Sjahrir, Yap Thiam Hien, Mohtar Lubis, Rahman Tolleng, and Aini Chalid. "Imagine, on January 11, still being embraced by Soeharto, on the 17th I was arrested," Hariman recalled. On January 11, Soeharto did accept Hariman with other student leaders at Bina Graha. Suharto intended to reduce student action. The figures were detained under the Anti-Subversion Law. Some of them were released a year after being held in prison, because they were proven not involved. The court, based on the Anti-Subversion Law, drew criticism.

\subsection{Malari 1974 as Discourse}

The Malari event still contains a dark side of history that we cannot fully understand, and perhaps because of that, this event is always interesting to discuss in the present context. In the Memory of General Yoga (1990), the event was described as the climax of student activities that had been going on since 1973. Yoga Sugomo was in New York when there was a riot on January 15, 1974. But five days after that he was called to Jakarta to replace Soetopo Juwono Head of BAKIN. 
In the Malari case, through the organization mass mobilization was carried out by Ramadi and Kyai Nur from Banten. Bambang Trisulo was said to have spent Rp. 30 million to pay for thugs. While Roy Simandjuntak mobilized pedicab drivers from around Senen. These activities - including the destruction of Japanese cars, Toyota Astra offices and Coca Cola - were carried out to damage the image of students and beat the duo of Soemitro-Soetopo Juwono. The contribution of other PSI intellectual thoughts came from economist Sarbini Sumawinata. In 1966, he argued that maintaining political stability was a condition for creating economic growth. The rationale then became a reference to the New Order's frame of mind.

Rahman Tolleng-in front of the Plenary Session of the Gotong Royong House of Representatives representing the Golkar Faction in 1969 - argued that the electoral system should be district based, replacing proportional representation. The district system is adopted by the United States. The district system allows direct relations between the elected and the voters. Elections are slowly becoming a qualitative election. Proposed Rahman was rejected, but the idea of a district system often appeared until now.

After going through ups and downs, the efforts of modern pluralists to arouse popular socialism in the New Order era finally failed in January 1974. The Malari incident was mentioned by David Bourchier and Vedi R. Hadiz as the culmination of the tension of modern pluralists with groups of officers, entrepreneurs and politicians in around Opsus led by Ali Moertopo.

After the Malari incident, modern pluralists were often in the vanguard of the opposition of the New Order. "After 1974, it seemed the door was closed to the rise of PSI, including its people," said Rahman Tolleng, a senior activist who imprisoned without legal process after the 1974 Malari riots.

Finally, In the 1974 Malari incident, it seemed clear that the press/media supported the student movement at the time, but were suppressed by the New Order authorities. The press/media banning was a sign that the New Order's authoritarianism was increasingly strong which could only be ended in May 1998.

\section{Conclusion}

For the newsmen/press activists in Indonesia, Hariman Siregar (born in Padang Sidempuan, North Sumatra, 1950) became a legend of Indonesian reform activists. He was with other student leaders, such as Syahrir, Muhammad Aini Chalid, Judilherry Justam, and others. Hariman was the main figure in the Malari incident on January 15, 1974. Before the historic event, he was General Chair of the University of Indonesia (DM-UI) Student Council after being elected through elections intervened by the New Order government through Ali Murtopo.

The Malari 1974 tragedy made a number of newspapers sympathize and side with Hariman Siregar's actions. But the newspapers later banned and never published again, a sign that the authoritarianism of the New Order did not recognize empathy and did not care about press freedom. Even for the New Order regime, the press / media must be supervised, controlled and if it does not comply, it will be banned forever.

Because of the Malari incident, Hariman and several other student leaders were later imprisoned for quite a long time by the New Order regime, and until then he was the "legendary icon" of the student movement in Indonesia, which should be appreciated dan respected by our students and young activists. $* * *$ 


\section{References}

Asvi Warman Adam, 'Malari 1974 dan Sisi Gelap Sejarah', Kompas 16 Januari 2003

Aditia Muara Padiatra, 'Introduction to Malari: Dari Situasi,Aksi, hingga Tusuh pada Awal Orde Baru 1970-1974', Jurnal Criksetra, Universitas Sriwijaya , Volusme 4 nomor 8 Agustus 2015, pp. 103-110

Aswab Mahasin, \& Ismed Natsir (eds.). Cendikiawan dan Politik. Jakarta: LP3ES, 1983, pp. 164-186.

Arief Budiman, 1983. Peranan Mahasiswa Sebagai Inteligensia, in Aswab \& Natsir, Ismed (ed). Cendikiawan dan Politik. Jakarta: LP3ES, 1983, pp. 143-163.

B. Wiwoho dan Bandjar Chaeruddin, Memori Jenderal Yoga. Penerbit Bina Rena Pariwara, April 1991

David Bourchier, Vedi R. Hadiz (Eds) Indonesian Politics and Society: A Reader, London: Routledge, 2003

Edward Apinall, Indonesia: moral force politics and the struggle against Authoritarianism , in Weis, Meredith L \& Aspinall, Edward (ed). Student Activism in Asia: Between Protest, and Powerlessness. London: University of Minnesota Press. 2012 pp. 153180.

G. Dwipayana dan Ramadhan KH , Soeharto: Pikiran, Ucapan, dan Tindakan Saya, Penerbit Citra Lamtoro Gung Persada, 1988

Hariman Siregar, Hati Nurani Seorang Demonstran, Jakarta: Mantika Media Utama, 1994.

Heru Cahyono, Pangkopkamtib Jenderal Soemitro dan Peristiwa Malari, Pustaka Sinar Harapan; first edition, 1992.

Julian Benda "La trahison des Clercs", English translation The Betrayal of the Intellectuals, by Richard Aldington: 1955, Beacon Press.

Masminar Mangiang "Mahasiswa, Ilusi tentang Sebuah Kekuatan", majalah Prisma (No. 12, Desember 1981)

Richard Halloranjan, "Violent Crowds in Jakarta Protest the Visit by Tanaka", New York Times, 16 Januari 1974.

Sutarto, Lubis, S., and Katimin. (2019). Political Imaging Techniques Carried Out by Baitul Muslimin Indonesia (BAMUSI) in Increasing Public Political Support for PDI Perjuangan Medan City. Budapest International Research and Critics InstituteJournal (BIRCI-Journal) Volume 2, No 3, August 2019, Page: 164-174.

Wiratmo Soekito, Keterlanggaran Batas-batas Kultural, in Mahasin, Aswab \& Natsir, Ismed (Ed). Cendikiawan dan Politik. Jakarta: LP3ES, 1983, pp. 164-186.

Widiarsi Agustina, Masalah Misterius Malari: Rusuh Politik Pertama Dalam Sejarah Orde Baru, penerbit Tempo, Jakarta: Tempo Publishing, 2014.

\section{Newspaper, magazines and internet:}

The newspapers and magazines were banned on Januari 21, 1974

Antara and Kompas daily, 21-22 Januari 1974

Kompas daily newspaper, 13-16 Januari 1974. Pedoman, Indonesia Raya, Abadi and Kompas daily, 16-21 Januari 1974

Reports and analysis Kompas, Pedoman, Abadi dan Indonesia Raya daily newspapers, 12

November 1973-20 Januari 1974.

Kompas, 16 Januari 1974.

Harian Abadi 4 Desember 1973

Harian Kompas, 3 Desember 1973

Majalah Tempo dalam Edisi Khusus Malari, 13 Januari 2014 
Pintu Tertutup untuk PSI, pernyataan Rosihan Anwar, Tempo edisi khusus, Senin, 09 Maret 2009

Tempo edisi khusus Senin, 09 Maret 2009

Statemen activists DM-UI , Tempo edisi khusus Senin, 09 Maret 2009

https://www.nytimes.com/1974/01/16/archives/violent-crowds-in-jakarta-protest-the-visitby-tanaka-thousands.html accessed 20 November 2018

\section{Interview:}

Interview with Hariman Siregar, Tokoh Malari dan General Chairman DM-UI Period 1973 - 1974, Jakarta 7 Mei 2015.

Interview with A. Rahman Tolleng, Jakarta, March 20, 2009. 